\title{
Faktor - Faktor yang Berhubungan dengan Minat Ibu dalam Pemilihan Alat Kontrasepsi IUD di Puskesmas Pasar Kota Prabumulih
}

\author{
Pera Mandasari \\ Akademi Kebidanan Rangga Husada Prabumulih
}

Informasi Artikel :

Diterima : 12 November 2020

Direvisi : 15 November 2020

Disetujui : 28 November 2020

*Korespondensi Penulis : dwipera86@yahoo.com

\section{A B S T R A K}

IUD atau Alat Kontrasepsi Dalam Rahim (AKDR) merupakan alat kontrasepsi terbaik bagi banyak kaum wanita. Alat ini sangat efektif dan tidak perlu diingat setiap hari seperti halnya pil. Bagi ibu yang menyusui, AKDR tidak akan mempengaruhi Air Susu Ibu (ASI), kelancaran ataupun kadar Air Susu Ibu (ASI). Karena itu, setiap calon pemakai AKDR perlu memperoleh informasi yang lengkap tentang seluk beluk alat kontrasepsi ini (manuaba, 2010).Tujuan penelitian adalah mengetahui faktor-faktor yang berhubungan dengan minat ibu dalam pemilihan alat kontrasepsi IUD di puskesmas pasar kota prabumulih tahun 2020. Penelitian ini menggunakan Survey Analitik dengan menggunakan pendekatan Cross Sectional. Populasi penelitian ini adalah ibu yang menggunakan alat kontrasepsi yang berjumlah 46 orang. Sampel berjumlah 46 responden. Pada analisa univariat didapatkan responden dari 46 responden didapatkan bahwa responden yang Berpengetahuan Baik 32 responden $(69,6 \%)$ dan responden yang Pengetahuannya Kurang 14 responden $(30,4 \%)$. Dukungan Suami sebanyak 30 responden $(65,2 \%)$ dan responden yang tidak mendapat dukungan sebanyak 16 responden $(34,8 \%)$. Kepemilikan BPJS sebanyak 31 responden $(67,4 \%)$ dan responden yang tidak memilik BPJS 15 responden $(32,6 \%)$.Analisa Bivariat menunjukkan Pengetahuan mempunyai hubungan yang bermakna dengan kontrasepsi IUD ( $\rho$ value 0,000), Dukungan Suami mempunyai hubungan yang bermakna dengan kontrasepsi IUD (pvalue 0,000), Kepemilikan BPJS mempunyai hubungan yang bermakna dengan kontrasepsi IUD ( $\rho$ value 0,000 ). Simpulan dari penelitian ini adalah bahwa ada faktor-faktor yang mempengaruhi dalam memilih kontrasepsi IUD di puskesmas pasar kota prabumulih tahun 2020 .

Kata Kunci : Pengetahuan, Dukungan, BPJS dan Kontrasepsi IUD

\section{ABSTRACT}

Intra Uterine Device (IUD) was contraception device inserted inti women' uterus. For most of women, it was the best contraseption. It was very effective because it was not remembered everday like pills commonly. For breast-feeding mothers, it was not influenced milk, supplied degree of mother. Because of the reason, new contraseption device user needed to get complete information about contraseption device (Manuaba,2010). The objective of the reseacrh was to know factor relating to mother's interest in selecting IUD contraseption tools in Puskesmas Pasar Prabumulih City in 2020. The research used analytical survey method of cross sectional approach. The population in study was all labor mother used contraseption about 46 people. The sample of the research was 46 respondents. In the univariate analysis, it was found that respondents from 46 respondents found that respondents with Good Knowledge 32 respondents $(69.6 \%)$ and respondents whose 
Knowledge was Less 14 respondents (30.4\%). Husband Support as many as 30 respondents $(65.2 \%)$ and respondents who did not get support as many as 16 respondents (34.8\%). BPJS ownership is 31 respondents (67.4\%) and respondents who do not have BPJS are 15 respondents (32.6\%). The Bivariate analysis showed Knowledge has a significant relationship with IUD contraception ( $\rho$ value 0,000), Husband Support has a significant relationship with IUD contraception ( $\rho$ value 0,000), BPJS ownership has a significant relationship with IUD contraception ( $\rho$ value 0,000). The conclusion of the reasearch was there ware factors relating to mother's interest in selecting IUD contraception tools in Puskesmas Pasar Prabumulih City in 2020.

\section{Keywords : Knowledge, Support, BPJS and IUD Contraception}

\section{PENDAHULUAN}

Intra Uterine Device (IUD) adalah salah satu Alat Kontrasepsi jangka panjang yang paling efektif dan aman dibandingkan Alat Kontrasepsi lainnya seperti pil. Alat Kontrasepsi IUD sangat efektif untuk menekan angka kematian ibu dan mengendalikan laju Pertumbuhan penduduk Karena tingkat efektifitas penggunaan sampai 99,4\% dan IUD dapat digunakan untuk jangka waktu 3-5 tahun (jenis hormon) 5-10 tahun (jenis tembaga). Alat Kontrasepsi IUD dimasukkan kedalam rahim yang bentuknya bermacammacam, terdiri dari plastik (polyethylene) (Handayani, 2010).

IUD atau Alat Kontrasepsi Dalam Rahim (AKDR) bagi banyak kaum wanita merupakan alat kontrasepsi yang terbaik. Alat ini sangat efektif dan tidak perlu diingat setiap hari seperti halnya pil. Bagi ibu yang menyusui, AKDR tidak akan mempengaruhi Air Susu Ibu (ASI), kelancaran ataupun kadar Air Susu Ibu (ASI). Karena itu, setiap calon pemakai AKDR perlu memperoleh informasi yang lengkap tentang seluk - beluk alat kontrasepsi ini (manuaba, 2010).

Menurut World Health Organization (WHO) (2014) penggunaan kontrasepsi telah meningkat di banyak bagian dunia, terutama di Asia dan Amerika Latin dan terendah di Sub-Sahara Afrika. Secara global, pengguna kontrasepsi modern telah meningkat tidak signifikan dari 54\% pada tahun 1990 menjadi $57,4 \%$ pada tahun 2014. Secara regional, proporsi pasangan usia subur 15-49 tahun melaporkan penggunaan metode kontrasepsi modern telah meningkat minimal 6 tahun terakhir. Di Afrika dari 23,6\% menjadi 27,6\%, di Asia telah meningkat dari $60,9 \%$ menjadi $61,6 \%$, sedangkan Amerika latin dan Karibia naik sedikit dari $66,7 \%$ menjadi $67,0 \%$.
Diperkiraan 225 juta perempuan di negaranegara berkembang ingin menunda atau menghentikan kesuburan tapi tidak menggunakan metode kontrasepsi apapun dengan alasan terbatas pilihan metode kontrasepsi dan pengalaman efek samping. Kebutuhan yang belum terpenuhi untuk kontrasepsi masih terlalu tinggi. Ketidak adilan didorong oleh pertumbuhan populasi (WHO, 2014).

Di Indonesia Tahun 2012 jumlah PUS sebanyak 45.189.997 orang dengan peserta Keluarga Berencana (KB) baru 9.388.374, yang terdiri dari Intra Uterine Device (IUD) (7,52\%), Metode Operasi Wanita (MOW) $(1,40 \%)$, Metode Operasi Pria (MOP) $(0,29 \%)$, Implant (8,59\%), Kondom (8,16\%), Suntik (46,94\%), Pil (27,09\%) Badan Kependudukan dan Keluarga Berencana Nasional (BKKBN,2012).

Data akseptor KB di provinsi Sumatera Selatan tahun 2018 yaitu KB suntik sebanyak 980.365 akseptor, KB implant sebanyak 405.634 akseptor, KB IUD sebanyak 397.866 akseptor dan KB lainnya sebanyak 673.922 akseptor (Dinas kesehatan Provinsi Sumatera Selatan, 2018).

Program yang dilakukan oleh pemerintah untuk mengurangi laju pertumbuhan penduduk dapat dilakukan dengan gerakan Keluarga Berencana dan pemakaian alat kontrasepsi secara sukarela kepada Pasangan Usia Subur (PUS). Gerakan keluarga berencana dilakukan untuk membangun keluarga yang sejahtera dalam rangka menciptakan sumber daya manusia yang optimal. Program Keluarga Berencana (KB) merupakan salah satu cara yang efektif untuk meningkatkan ketahanan keluarga, kesehatan, dan keselamatan ibu, anak, serta perempuan Badan Kependudukan dan Keluarga Berencana Nasional (BKKBN, 2015). 
Kebijakan pemerintah tentang $\mathrm{KB}$ saat ini mengarah pada pemakaian Metode Kontrasepsi jangka panjang (MKJP) (Balitbangkes, 2013).

Rizal Damanik, (2019) Mengungkapkan Pertumbuhan penduduk kian terjadi, namun angka fertilitas total di indonesia turun dari 2,6 anak per wanita di tahun 2012 dan tahun 2017 menjadi 2,4. Penurunan jumlah kelahiran di indonesia dapat dikaitkan dengan meningkatkan pemakaian kontrasepsi melalui semua cara, seperti pil $\mathrm{KB}$, Intra Uterine Device (IUD), kondom dan lainnya. Pemakainan kontrasepsi meningkat sebanyak 2 persen menjadi 64 persen di Survei Demografi dan Kesehatan Indonesia (SDKI), 2017. Kontrasepsi adalah upaya unutuk mencegah terjadinya kehamilan. Upaya untuk mencegah kehamilan dengan menggunakan Alat kontrasepsi yaitu KB permanen (tubektomi) dan KB sementara seperti implant, suntikan, pil, kondom, Alat Kontrasepsi Dalam Rahim (AKDR) atau IUD.

Teori Health Belief Model (HBM) Lewis, (1954) dalam Notoatmodjo, (2008) mengungkapkan bahwa rendahnya minat Metode Kontrasepsi Jangka Panjang (MKJP) seperti IUD dipengaruhi oleh persepsi individual mengenai ancaman dan pertimbangan untung rugi. Persepsi individu dipengaruhi faktor pemodifikasi yaitu usia, pendidikan, pengetahuan, jumlah anak, paparan sumber informasi dan kondisi ekonomi.

Menurut Yati Nur, (2019) Kurangnya Pengetahuan ibu seperti cara pemasangan dan seperti apa bentuk alat kontrasepsi IUD membuat ibu takut untuk mencoba alat kontrasepsi IUD. Serta Ketakutan suami atas ketidak nyamanan saat berhubungan intim nanti, Membuat suami tidak memberikan izin pada istrinya untuk memilih alat kontrasepsi IUD. Dan banyaknya persyaratan yang harus dilengkapi untuk menggunakan alat kontrasepsi IUD dengan Kartu BPJS membuat ibu enggan untuk melengkapinya, Sedangkan untuk membayar sendiri ibu tidak mempunyai biaya dikarenakan pemasangan IUD yang tidak murah.

Menurut Risa, (2015) Setelah dilakukan survey pendahuluan melalui wawancara dengan penanggung jawab (Kesehatan Ibu dan Anak) KIA/KB puskesmas, diperoleh informasi bahwa tidak semua PUS berminat terhadap IUD, dikarenakan berbagai alasan yang berbeda-beda seperti adanya rasa malu, takut efek samping, takut proses pemasangan dan kurang mengetahui tentang KB IUD, sehingga pada tahun 2012 dari 884 akseptor hanya 3 orang $(0,33 \%)$ yang menggunakan KB IUD. Mengungkapkan terdapat empat faktor yang mempengaruhi minat ibu untuk menggunakan Alat Kontrasepsi IUD yakni faktor pengetahuan, agama, ekonomi, dan budaya.(Eny, 2018).

Desitavani, (2017) menyatakan bahwa ada hubungan antara pendidikan, pekerjaan, sosial ekonomi, budaya, tingkat pengetahuan dan dukungan suami dengan pemilihan alat kontrasepsi IUD, dan tidak ada hubungan antara umur dan paritas dengan pemilihan alat kontrasepsi IUD.

Berdasarkan hasil penelitian Yati Nur, 2019 di Kelurahan Sidodsdi Kecamatan Wonomulyo secara statistik dengan menggunakan uji Chi-Square. Hasil analisis hubungan dengan minat ibu dalam pemilihan alat kontrasepsi IUD menunjukkan pada taraf signifikansi $>0,05$ diperoleh nilai signifikansi sebesar nilai $\mathrm{p}=0,149$ untuk pengetahuan, nilai $\mathrm{p}=0,009$ untuk dukungan suami, nilai $\mathrm{p}=0,132$ untuk kepemilikan BPJS, nilai $\mathrm{p}=0,440$ untuk media.

Data yang diperoleh dari Puskesmas Pasar Kota Prabumulih pada tahun 2019 untuk jumlah seluruh akseptor KB 477 orang, yang menggunakan KB Pil 151 orang, KB Suntik 141 orang, KB Implant 81 orang,dan KB IUD 41 orang (Rekam medik Puskesmas Pasar Kota Prabumulih, 2019).

\section{METODE PENELITIAN}

Desain Penelitian adalah rancangan penelitian yang ditetapkan dengan tujuan agar penelitian dapat dilakukan secara efektif dan efesien. Penelitian ini menggunakan metode kuantitatif dengan pendekatan survey analitik yaitu survei atau penelitian yang mencoba menggali bagaimana dan ,mengapa fenomena kesehatan itu terjadi, dengan pendekatan Cross Sectional yaitu studi epidemiologi yang mempelajari prevalensi, distribusi maupun hubungan penyakit Penelitian difokuskan pada faktor-faktor yang berhubungan dengan minat ibu dalam pemilihan alat kontrasepsi IUD di Puskesmas Pasar Kota prabumulih Tahun 2019 Untuk diberikan secara komprehensif (Notoatmodjo, 2014).

\section{HASIL PENELITIAN}

\section{A. Analisis Univariat}

Tabel 1 Distribusi Frekuensi Responden berdasarkan Kontrasepsi IUD di Puskesmas Pasar Kota Prabumulih tahun 2020 
Jurnal Kebidanan :Jurnal Medical Science Ilmu Kesehatan Akademi Kebidanan Budi Mulia Palembang Volume.10 No.2, Desember 2020

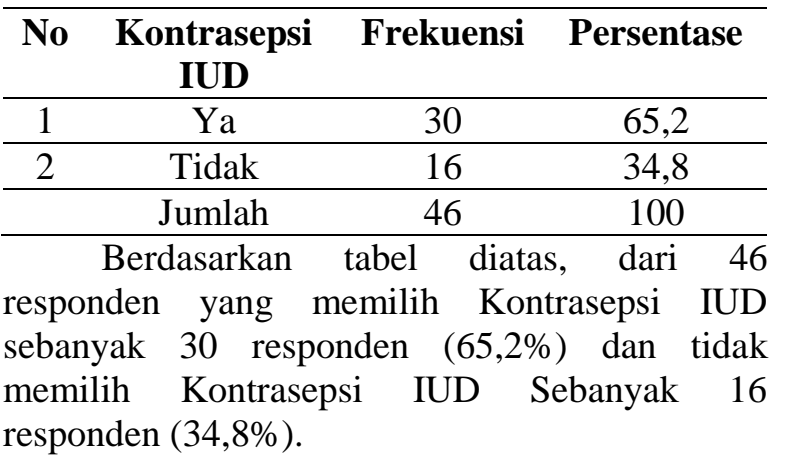

\section{Pengetahuan Ibu}

Tabel 2 Distribusi Frekuensi Responden Pengetahuan Ibu di Puskesmas Pasar Kota Prabumulih Tahun 2020

\begin{tabular}{ccccc}
\hline No & $\begin{array}{c}\text { Pengetahuan } \\
\text { Ibu }\end{array}$ & Frekuensi & $\mathbf{( \% ) ~}$ \\
\hline 1 & Baik & 32 & 69,6 & \\
\hline 2 & Kurang & 14 & 30,4 & \\
\hline & Jumlah & 46 & 100 & \\
\hline & Berdasarkan & Tabel diatas & dari & 46
\end{tabular}
responden terdapat 32 responden $(69,6 \%)$ yang memiliki Pengetahuan yang Baik dibanding dengan Pengetahuan yang Kurang yaitu 14 responden $(30,4 \%)$.

\section{Dukungan Suami}

Tabel 3 Distribusi Frekuensi Responden Dukungan Suami di Puskesmas PAsar Kota Prabumulih Tahun 2020

\begin{tabular}{ccccc}
\hline No & $\begin{array}{c}\text { Dukungan } \\
\text { Suami }\end{array}$ & Frekuensi & $\mathbf{( \% ) ~}$ \\
\hline 1 & Ya & 30 & 65,2 & \\
\hline 2 & Tidak & 16 & 34,8 & \\
\hline & Jumlah & 46 & 100 & \\
\hline & Berdasarkan & Tabel diatas & dari & 46
\end{tabular}
responden terdapat 30 responden $(65,2 \%)$ yang mendapat Dukungan Suami lebih banyak dibanding dengan responden yang tidak mendapat Dukungan Suami Yaitu 16 orang $(34,8 \%)$.

\section{Kepemilikan BPJS}

Tabel 4 Distribusi Frekuensi Responden Kepemilikan BPJS di Puskesmas Pasar Kota Prabumulih Tahun 2020

\begin{tabular}{|c|c|c|c|}
\hline No & $\begin{array}{c}\text { Kepemilikan } \\
\text { BPJS }\end{array}$ & Frekuensi & $(\%)$ \\
\hline 1 & $\mathrm{Ya}$ & 31 & 67,4 \\
\hline 2 & Tidak & 15 & 32,6 \\
\hline & Jumlah & 46 & 100 \\
\hline
\end{tabular}

responden terdapat 31 responden $(67,4 \%)$ yang

Memiliki BPJS lebih banyak dibanding dengan responden yang tidak Memiliki BPJS yaitu 15 orang $(32,6 \%)$.

\section{b. Analisis Bivariat}

Analisa bivariat ini dilakukan untuk mengetahui hubungan variabel Independen yaitu Pengetahuan Ibu Dukungan Suami, Kepemilikan BPJS dan variabel dependen yaitu Kontrasepsi IUD. Uji statistik yang digunakan adalah uji chi square sistem Komputerisasi dengan batas kemaknaan $\rho$ value $<0,05$ yang berarti terdapat hubungan yang bermakna.

Tabel 5 Hubungan Pengetahuan Ibu dengan Kontrasepsi IUD di Puskesmas Pasar Kota Prabumulih tahun 2020

\begin{tabular}{cccccccc}
\hline \multirow{2}{*}{$\begin{array}{c}\text { Pengetahuan } \\
\text { Ibu }\end{array}$} & \multicolumn{4}{c}{ Kontrasepsi IUD } & \multirow{2}{*}{ Jumlah } & \multirow{2}{*}{$\boldsymbol{P}$} \\
\cline { 2 - 6 } & \multicolumn{2}{c}{ Ya } & \multicolumn{2}{c}{ Tidak } & & & Value \\
\cline { 2 - 7 } & $\mathrm{N}$ & $\%$ & $\mathrm{~N}$ & $\%$ & $\mathrm{~N}$ & $\%$ & \\
\hline Baik & 28 & 60,9 & 4 & 8,7 & 32 & 100 & \multirow{2}{*}{0,0} \\
\hline Kurang & 2 & 4,3 & 12 & 26,1 & 14 & 100 & 00 \\
\hline Jumlah & $\mathbf{3 0}$ & $\mathbf{6 5 , 2}$ & $\mathbf{1 6}$ & $\mathbf{3 4 , 8}$ & $\mathbf{4 6}$ & $\mathbf{1 0 0}$ & \\
\hline
\end{tabular}

Dari tabel diatas, dapat dilihat bahwa dari 46 responden didapatkan 28 responden $(60,9 \%)$ yang memilih alat kontrasepsi IUD dan $4(8,7 \%)$ responden yang tidak memiliki alat Kontrasepsi IUD dan responden yang pengetahuan rendah terdapat $2(4,3 \%)$ responden yang memiliki alat kontrasepsi IUD dan $12(26,1 \%)$ responden yang tidak memiliki alat kontrasepsi IUD.

Berdasarkan hasil analiasa bivariat dengan Uji statistic Chi-Square didapatkan $p$ value $=$ 0,000 berarti hipotesis menyatakan bahwa ada hubungan yang bermakna antara Pengetahuan Ibu dengan Kontrasepsi IUD terbukti.

Tabel 6 Hubungan Dukungan Suami dengan Kontrasepsi IUD di Puskesmas Pasar Kota Prabumulih Tahun 2020

\begin{tabular}{|c|c|c|c|c|c|c|c|}
\hline \multirow{3}{*}{$\begin{array}{l}\text { Dukungan } \\
\text { Suami }\end{array}$} & \multicolumn{4}{|c|}{ Kontrasepsi IUD } & \multirow{2}{*}{\multicolumn{2}{|c|}{ Jumlah }} & \multirow{3}{*}{$\begin{array}{c}P \\
\text { Value }\end{array}$} \\
\hline & \multicolumn{2}{|c|}{ Ya } & \multicolumn{2}{|c|}{ Tidak } & & & \\
\hline & $\mathrm{N}$ & $\%$ & $\mathrm{~N}$ & $\%$ & $\mathrm{~N}$ & $\%$ & \\
\hline $\mathrm{Ya}$ & 30 & 65,2 & 0 & 0 & 30 & 100 & \multirow{3}{*}{0,000} \\
\hline Tidak & 0 & 0 & 16 & 34,8 & 16 & 100 & \\
\hline Jumlah & 30 & 65,2 & 16 & 34,8 & 46 & 100 & \\
\hline
\end{tabular}

Dari tabel diatas, dapat dilihat bahwa dari 46 responden didapatkan 30 responden $(65,2 \%)$ yang memilih alat kontrasepsi IUD dan $0(0 \%)$ responden yang tidak memiliki alat Kontrasepsi IUD dan responden yang pengetahuan rendah terdapat $0(0 \%)$ responden yang memiliki alat kontrasepsi IUD dan $16(34,8 \%)$ responden yang tidak memiliki alat kontrasepsi IUD. 
Jurnal Kebidanan :Jurnal Medical Science Ilmu Kesehatan Akademi Kebidanan Budi Mulia Palembang Volume.10 No.2, Desember 2020

Berdasarkan hasil analiasa bivariat dengan Uji statistic Chi-Square didapatkan $p$ value = 0,000 berarti hipotesis menyatakan bahwa ada hubungan yang bermakna antara dukungan suami Ibu dengan Kontrasepsi IUD terbukti.

Tabel 7 Hubungan Kepemilikan BPJS dengan Kontrasepsi IUD di Puskesmas Pasar Kota Prabumulih Tahun 2020

\begin{tabular}{|c|c|c|c|c|c|c|c|}
\hline \multirow{3}{*}{$\begin{array}{c}\text { Kepemilikan } \\
\text { BPJS }\end{array}$} & \multicolumn{4}{|c|}{ Kontrasepsi IUD } & \multirow{2}{*}{\multicolumn{2}{|c|}{ Jumlah }} & \multirow{3}{*}{$\begin{array}{c}P \\
\text { Value }\end{array}$} \\
\hline & \multicolumn{2}{|c|}{ Ya } & \multicolumn{2}{|c|}{ Tidak } & & & \\
\hline & $\mathrm{N}$ & $\%$ & $\mathrm{~N}$ & $\%$ & $\mathrm{~N}$ & $\%$ & \\
\hline Ya & 26 & 56,5 & 5 & 10,9 & 31 & 100 & \multirow{3}{*}{0,000} \\
\hline Tidak & 4 & 8,7 & 11 & 23,9 & 15 & 100 & \\
\hline Jumlah & 30 & 65,2 & 16 & 34,8 & 46 & 100 & \\
\hline
\end{tabular}

Dari tabel diatas, dapat dilihat bahwa dari 46 responden didapatkan 26 responden $(56,5 \%)$ yang memilih alat kontrasepsi IUD dan $4(8,7 \%)$ responden yang tidak memiliki alat Kontrasepsi IUD dan responden yang pengetahuan rendah terdapat $5(10,9 \%)$ responden yang memiliki alat kontrasepsi IUD dan $11(23,9 \%)$ responden yang tidak memiliki alat kontrasepsi IUD.

Berdasarkan hasil analiasa bivariat dengan Uji statistic Chi-Square didapatkan $p$ value $=$ 0,000 berarti hipotesis menyatakan bahwa ada hubungan yang bermakna antara kepemilikan BPJS dengan Kontrasepsi IUD terbukti.

\section{PEMBAHASAN}

Faktor-faktor yang berhubungan dengan pemilihan alat kontrasepsi IUD yaitu pengetahuan, dukungan suami dan kepemilikan kartu BPJS terdapat hubungan yang bermaknaPenelitian ini sejalan dengan penelitian yang dilakukan Yati Nur, (2019) di Kelurahan Sidodadi Kecamatan Wonomulyo secara statistik dengan menggunakan uji Chi-square di peroleh nilai $\rho>0,05$ dengan demikian Ho ditolak dan $\mathrm{Ha}$ diterima yang artinya ada hubungan antara pengetahuan ibu dengan minat dalam pemilihan alat kontrasepsi IUD dengan nilai $\rho$ value $=0,000$. Ketakutan suami atas ketidak nyamanan saat berhubungan intim nanti, Membuat suami tidak memberikan izin pada istrinya untuk memilih alat kontrasepsi IUD, Dan bila suami memberikan Dukangan maka istri berani mengambil keputusan untuk memilih alat kontrasepsi IUD. Penelitian ini sejalan dengan penelitian yang dilakukan Yati Nur, (2019) di Kelurahan Sidodadi Kecamatan Wonomulyo secara statistik dengan menggunakan uji Chisquare di peroleh nilai $\rho>0,05$ dengan demikian Ho ditolak dan Ha diterima yang artinya ada hubungan pengetahuan ibu dengan minat dalam pemilihan alat kontrasepsi IUD dengan nilai $\rho$ value $=0,000$.

\section{KESIMPULAN}

Ada hubungan yang bermakna antara Pengetahuan Ibu dengan alat Kontrasepsi IUD di Puskesmas Pasar Kota Prabumulih Tahun 2020, dimana $\rho$ value $=(0,000)<0,05$. Ada hubungan yang bermakna antara Dukungan Suami dengan alat Kontrasepsi IUD di Puskesmas Pasar Kota Prabumulih Tahun 2020, dimana $\rho$ value = $(0,000)<0,05$. Ada hubungan yang bermakna antara Kepemilikan BPJS dengan alat kontrasepsi IUD di Puskesmas Pasar Kota Prabumulih Tahun 2020, dimana $\rho$ value $=(0,000)<0,05$.

\section{DAFTAR PUSTAKA}

Balitbangkes.2013.Kebijakan pemerintah tentang $K b$.

\section{BKKBN.2012.Jumlah PUS dengan Keluarga Berencana.}

Damanik,Rizal.2019.survei Demografi dan Kesehatan Indonesia.

Desitavani.2017.Hubungan yang Mempengaruhi minat ibu untuk menggunakan alat kontrasepsi IUD

Eny.2018.Faktor yang mempengaruhi Minat Ibu untuk menggunakan kontrasepsi IUD.

Handayani.2010.Alat kontrasepsi Ihatan Alat Kontrasepsi IUD dan Kb.

Manuaba.I.B.G.2010.Ilmu Kesehatan Alat kontrasepsi.Jakarta.EGC.

Notoatmodjo,S.2010.Ilmu Kesehatan Masyarakat.Jakarta.Rineka Cipta.

\section{Saifuddin.2012.kontraindikasi dan kerugian alat kontrasepsi IUD.}

Sari.Yati nur indah.2019.faktor-faktor yang berhubungan dengan minat ibu dalam pemakaian alat kontrasepsi IUD 
